\title{
Nomenclature and Classification of Viruses
}

\section{International Committee on Nomenclature of Viruses}

The International Committee on Nomenclature of Viruses (ICNV) was established at the Ninth International Congress for Microbiology in Moscow, in September 1966. The second meeting of the Committee was held in Mexico City at the time of the Tenth International Congress for Microbiology in Mexico City in August 1970. Following the decisions of this meeting, the First Report of ICNV, entitled "Classification and Nomenclature of Viruses," has been produced as a monograph, edited by the President of ICNV, P. Wildy, and was published in June 1971 by S. Karger, Basel, as No. 5 of its series "Monographs in Virology."

At the meeting in Mexico City, the Executive Committee (ECICNV) and its Subcommittees were reconstituted, and the composition of ICNV was reorganized. The present Executive Committee met for the first time at the time of the Second International Congress for Virology in Budapest in June 1971. The next meeting of the Executive Committee will be held in 1973. In 1975, coinciding with the Third International Congress for Virology, the ECICNV will meet and there will be a Plenary Session of ICNV.

ICNV now comprises one member for each national member-society of the International Association of Microbiological Societies, a small number of life members, those members of the Executive Committee who are not already national or life members, and all members of the six subcommittees of the Executive Committee.

The Executive Committee and the Subcommittees. The Executive Committee consists of a number of elected members plus the Chairman of each of its Subcommittees if he is not already an elected member. The present composition of the Executive Committee is as follows:

\section{F. J. Fenner (Australia), President}

J. Maurin (France) Y Permanent

V. Valenta (Czechoslovakia) Secretaries

H. S. Ginsberg (USA), Vice-President

A. Lwoff (France)

K. Maramorosch (USA)

J. L. Melnick (USA)

E. Norrby (Sweden)

A. J. Rhodes (Canada)

J. P. H. van der Want (Netherlands)

V. M. Zhdanov (USSR)

A. Eisenstark (Chairman, Bacterial Virus Subcommittee)

Division of Biological Sciences

University of Missouri

Columbia, Mo. 65201 USA
A. J. Gibbs (Chairman, Code \& Data Subcommittee) Department of Developmental Biology

Research School of Biological Sciences

Australian National University

Canberra, Australia

H. G. Pereira (Chairman, Vertebrate Virus Subcommittee)

National Institute of Medical Research

The Ridgeway, Mill Hill

London, NW7, England

R. J. Shepherd (Chariman, Plant Virus Subcommittee)

Department of Plant Pathology

University of California

Davis, Calif. 95616

C. Vago (Chairman, Invertebrate Virus Subcommittee) Universite de Montpellier

Laboratoire de Pathologie Comparee

Place Eugine Batailon

Montpellier, France

P. Wildy (Chairman, Coordination Subcommittee)

Department of Virology

The Medical School

The University of Birmingham

Birmingham, B15 2TJ, England

Action by ICNV between meetings. From time to time between now and 1975, when the next meeting of ICNV will be held, decisions on what are likely to be noncontroversial matters will be made by postal ballot of ECICNV and ICNV. For example, it should be possible to make decisions on the names of newly recognized groups of viruses, decisions which are acceptable according to the Rules of ICNV. The results of these decisions will be published in representative virological journals.

Decisions on controversial matters, such as amendments to the Rules governing nomenclature, require full discussion, which will be possible only at the Plenary Sessions of ICNV. Proposals for amendments to the Rules (which are set out in the First Report of the International Committee on Nomenclature of Viruses, referred to earlier) must be made in writing to one of the Permanent Secretaries one year before the next Plenary Session of ICNV, i.e., before September 1974. Any such proposal should be be accompanied by a supporting statement setting out the reasons for the amendment.

Virologists are urged to forward any suggestions they may have relating to the classification or nomenclature of viruses to the Chairman of the relevant Subcommittee of ICNV.

Frank Fenner, President International Committee on Nomenclature of Viruses 